\title{
Current Status of Biosimilar Growth Hormone
}

\author{
Paul Saenger \\ Albert Einstein College of Medicine, Bronx, NY 10467, USA \\ Correspondence should be addressed to Paul Saenger, phsaenger@aol.com
}

Received 7 July 2009; Accepted 16 July 2009

Recommended by Ron Rosenfeld

As the first wave of biopharmaceuticals is set to expire, biosimilars or follow-on protein products (FOPPs) have emerged. The regulatory foundation for these products is more advanced and better codified in Europe than in the US. Recent approval of biosimilar Somatropin (growth hormone) in Europe and the US prompted this paper. The scientific viability of biosimilar growth hormone is reviewed. Efficacy and safety data (growth rates, IGF-1 generation) for up to 7 years for pediatric indications measure up favorably to previously approved growth hormones as reference comparators. While the approval in the US is currently only for treatment of growth hormone deficiency (GHD) in children and adults, the commercial use of approved biosimilar growth hormones will allow in the future for in-depth estimation of their efficacy and safety in non-GH deficient states as well.

Copyright () 2009 Paul Saenger. This is an open access article distributed under the Creative Commons Attribution License, which permits unrestricted use, distribution, and reproduction in any medium, provided the original work is properly cited.

\section{Introduction}

Recombinant protein drugs approved by the FDA over the past 25 years have become a cornerstone of medical and especially endocrine practice [1] (Table 1).

As the first wave of biopharmaceuticals has expired or is about to approach expiry, the opportunity for the development of subsequent biosimilar or follow-on protein product (FOPP) versions of these products has emerged. However, second entry biopharmaceuticals differ significantly from traditional chemical generics (Table 2).

In the standard pharmaceutical sector, competition from cost-effective generic medicines is encouraged for many years now to stimulate innovation and to free up health care budget resources [1].

Biosimilars, unlike conventional generic drugs, require more quality data and therefore must demonstrate full comparability (including immunogenicity data), to the reference product. This of course begs the question: what is the incentive to develop a biosimilar? Unlike with traditional generic products, there is the potential in Europe to extrapolate to all indications of the reference product (in this case Humatrope or Genotropin), which may go part of the way answering this question [2].

One way this is achieved is by providing an abridged registration procedure which allows an applicant to apply for marketing authorization of a patent-free medicine to replace full clinical trials with noninferiority bioequivalence studies. The manufacturer must prove the quality of the generic product and, since the safety and efficacy of the active substance are already well known, the generic has to demonstrate its therapeutic equivalence with the original product through what are called bioequivalence studies [3].

\section{Historical Perspectives}

Due to the complexity of biotechnology-derived products and the sensitive manufacturing process involved, the standard generic approach is not appropriate for biopharmaceuticals, and a specific legal pathway for the registration of these products was needed. In the EU, the current provisions of European Medical Evaluation Agency (EMEA) for approval of what have come to be called "similar biological medicinal products or biosimilars" have been in force since October 2005 (Guideline on Similar Biological Medicinal Products) [4]).

Therefore "biosimilar" does not designate second-entry versions of biopharmaceuticals whose patent protection has expired, but rather a high quality product just as in new drug applications (NDAs). Authorization of biosimilars is granted on the basis of the strict guidelines of European drug law, 
TABLE 1: Classes of approved recombinant-protein drugs [1].

\begin{tabular}{ll}
\hline Class & Examples \\
Hormones & $\begin{array}{l}\text { Insulin (e.g., Humulin), glucagon (e.g., Glucagen), human growth hormone (e.g., Humatrope), thyrotropin } \\
\text { (Thyrogen), follicle-stimulating hormone (Gonal-F), lutelnizing hormone (lutropin alfa [Luveris]), human } \\
\text { chorionic gonadotropin (Ovidrel), erythropoietin (e.g., epoctin alfa [Epogen]) }\end{array}$ \\
\hline Cytokines & $\begin{array}{l}\text { Interferon alfa (e.g., Roferon-A), granulcyte-colony-stimulating factor (filgrastim [Neupogen]), interleukin } \\
\text { (e.g., aldesleukin [Proleukin]) }\end{array}$ \\
\hline Clotting factors & Factor VII (NovoSeven), factor VIII (e.g., Kogenate), factor IX (BeneFIX) \\
\hline Monoclonal antibodies & $\begin{array}{l}\text { Antibodies to vascular endothelial growth factor (bevacizumab [Avastin]), epidermal growth factor receptor } \\
\text { (cetuximab [Erbitux]), GPIIb/IIIa receptor (abciximab [ReoPro]), CD20 (rituximab [Rituxan]), and TNF- } \alpha \\
\text { (e.g., infliximab [Remicade]) }\end{array}$ \\
\hline Eaccine products & $\begin{array}{l}\text { Hepatitis B surface antigen (e.g., Recomblvax HB), Borrelia burgdorferi outer sourface protein A (LYMErix), + } \\
\text { human papillomavirus major capsid proteins (Gardasil) }\end{array}$ \\
\hline Ovel synthetic proteins & $\begin{array}{l}\text { Glucocerebrosidase (Cerezyme), DNase (Pulmozyme), thrombolytics (e.g., alteplase [Activase]), urate oxidase } \\
\text { (rasburicase, Elitek) }\end{array}$ \\
\hline $\begin{array}{l}\text { Fusion protein of interleukin-2 and diphtheria toxin (denileukin diftitox [Ontak]), soluble TNF receptor linked } \\
\text { to IgG Fc (etanercept [Enbrel]) }\end{array}$ \\
$\begin{array}{l}\text { Pegylated proteins: interferon (peginterferon alfa-2a [Pegasys]), granulocyte colony-stimulating factor } \\
\text { (pegfilgrastim [Neulasta]), human growth hormone (pegvisomant [Sornavert]) } \\
\text { Covalently attached metal chelators: ibrutumomab tiuxetan (Zevalin) } \\
\text { Covalently attached radioactive iodine: Iodine-131 tositumomab (Bexxar) } \\
\text { Covalently attached chemotherapeutics: gemtuzumab ozogarnicin (Mylotarg) }\end{array}$ \\
\hline
\end{tabular}

which requires in-depth proof that the second-entry product is similar to the original product in terms of quality, safety, and efficacy.

An important prerequisite for the development of biosimilars or FOPPs has been the advances in analytics seen over the past two decades. Twenty years ago, available analytical technologies were not refined enough to allow an in-depth physicochemical comparison of complex protein molecules and protein drugs were therefore not amenable to direct laboratory comparisons. Quality depended on a consistent controlled and reproducible manufacturing process.

Today's analytical techniques enable in-depth investigation of all the relevant properties of a recombinant protein or glycoprotein regarding its primary, secondary, tertiary and quaternary structures, allowing direct and thorough comparison of the quality and characteristics of biopharmaceuticals [4].

In the US this process was seriously delayed by several years after a "Citizen' s Petition" was filed by both Pfizer and Genentech to disallow the approval of biosimilars by the FDA [1].

Sandoz patiently only sought approval for Omnitrope, a recombinant human growth hormone that is structurally identical to Pfizer's Genotropin, which itself was approved under a 1995 new-drug application (NDA). As part of its application, Sandoz submitted chemical data, bioassays in hypophysectomized rats, safety studies in rats and rabbits, human pharmacokinetic and pharmacodynamic (PK/PD) studies and results of phase III studies (see, below for details). After a year of deliberations the FDA decided that it was unable "to reach a decision on the approvability of the application because of unresolved scientific and legal issues"
[5]. Sandoz sued and after protracted legal wrangling from 2003 to 2007 Omnitrope and Valtropin, another FOPPs from Korea manufactured by LG Life Sciences in collaboration with Biopartners from Switzerland were finally approved in 2007 after a District Court instructed the FDA to end its "marathon round of keep-away" [1] and make a decision about the product $[1,5]$. It is true that in 2007 bills were introduced in the US Congress with the goal of creating a viable abbreviated approval scheme for FOPPs. Although there was some well meaning talk that one of the bills would be included in the recently passed FDA Amendment Act, unfortunately none reached a floor vote [1] and the US approval process continues to lag seriously behind Europe, which recently also approved biosimilar erythropoetin as well granulocyte colony stimulating factor (GCSF) (Sandoz, Press Release 2008).

When the FDA ultimately approved Omnitrope and Valtropin, it allowed an abbreviated pathway with at least 6-month clinical data from a phase III study. It did so only because hGH had been historically regulated under the Federal Food Drug and Cosmetic Act (FFDCA) and not under Public Health Service Act (PHSA) from 1944 which regulates most protein-based products in the US, for example, Interferon. Fortunately, a few select recombinant products such as insulin, glucagons, hGH, and thyrotropin alpha are governed under the FFDCA from 1938 and are approved in the US under new-drug applications [1].

In its approval the FDA finally acknowledged that a comparison of "end products of different manufacturing processes was possible in select cases because of improvements in the availability of analytical techniques." Omnitrope, and implicitly also Valtropin, were approvable because "it had a well characterized protein structure, a known 
TABle 2: Comparison of data requirement for generics versus similar biological medicinal products. BE: bioequivalence; PMS: postmarketing study.

\begin{tabular}{|c|c|c|}
\hline \multicolumn{2}{|c|}{ Classic generics } & Biosimilars \\
\hline \multirow{5}{*}{ Manufacturing } & Chemical synthesis & $\begin{array}{l}\text { Genetically modified cell } \\
\text { lines }\end{array}$ \\
\hline & $\begin{array}{l}\text { Simple microbial } \\
\text { fermentation }\end{array}$ & $\begin{array}{l}\text { Complex fermentation } \\
\text { process }\end{array}$ \\
\hline & \multirow[t]{3}{*}{ Standard analytics } & $\begin{array}{l}\text { Complex purification } \\
\text { process }\end{array}$ \\
\hline & & Formulation \\
\hline & & $\begin{array}{l}\text { Complex analytical } \\
\text { characterization }\end{array}$ \\
\hline \multirow{4}{*}{ Preclinic } & \multirow{4}{*}{ Generally none } & In vitro/in vivo bioassay \\
\hline & & Toxicity studies \\
\hline & & Local tolerance studies \\
\hline & & PK/PD studies \\
\hline \multirow{4}{*}{ Clinic } & \multirow{4}{*}{ Generally BE study } & Phase I PK/PD \\
\hline & & Phase III studies \\
\hline & & Phase IIIb studies \\
\hline & & Phase IV studes (PMS) \\
\hline
\end{tabular}

mechanism of action, a lack of glycosylation and a long and well documented history of clinical use with a safety and efficacy profile thoroughly described in the literature" [1]. The FDA should also be able to rely on studies and analyses done to secure EMEA, Canadian, or Australian approval.

Even though the EMEA [6-8] and US approval process requires phase III studies, for example, hGH [9] it did have a marked effect on lowering costs, contrary to expectations in the US Senate [10].

Some scientific issues which have led well-meaning critics to doubt the clinical utility and safety of FOPPs do remain unresolved [1]. Most notably the potential for complex quaternary structure, $\mathrm{PD}$, and immunogenicity, is owing to changes in manufacturer, inert ingredients and packaging. For example, in the case of Eprex, a DNA recombinant erythropoietin, not a biosimilar, serious problems arose when a stabilizer in the manufacturing process was changed from albumin to sorbitol antierythropoietin; antibodies were formed and potentially lethal pure red call aplasia developed as a most serious side effect [13-15]. Thus postmarketing pharmacovigilance studies will probably be required for all except the simplest FOPPS for the foreseeable future. These provisions regarding Phase IV studies are also in place for Omnitrope in the US and Europe and will also be carried out for Valtropin once it is being marketed.

In summary two biosimilar somatropins Omnitrope (Sandoz) and Valtropin (LG Life Sciences, Biopartners) have recently in 2007 been approved by the US Food and Drug Administration and previously by EMEA [6-8] as a follow on protein product. Omnitrope is being marketed in the US since 2007 for GHD in children and adults. Valtropin is not yet on the market, except in Korea.

\section{Biosimilars and Fopps for GH in the US}

Biosimilar designates a second entry version of a biopharmaceutical whose patent protection expired. The term is considered equivalent to FOPP. It is only reasonable to study metabolic effects of a FOPP in a very sensitive population, that is, Growth hormone deficiency. Once efficacy is demonstrated in that model it is extremely unlikely that the drug will behave suddenly differently in a less sensitive model (e.g., SGA or Turner Syndrome) [4].

In the FDA ruling neither drug was rated as therapeutically equivalent and therefore substitutable for any of the other approved growth hormone products. That is why this class of drugs is more appropriately characterized as a "follow-on protein product."

There are currently in the US two possible pathways for approval for follow on protein product, either are found in section 505 of the Food, Drug and Cosmetic (FDC) Act applicable to drugs or under section 351 of the PHS Act applicable to biological products. Omnitrope was approved under section 505(b) 2 of the FDC Act which is usually applied to generic drugs and allows for an abbreviated approval pathway. In the previous years the FDA approved also other follow-on products under section 505 of the FDCA. These include GlucaGen (glucagons recombinant for injection), Hylenex (Hyaluronidase recombinant human), and Fortical (calcitonin salmon recombinant) Nasal Spray [1].

\section{Clinical Studies with Approved Biosimilar Growth Hormones}

Following guidelines published first by EMEA in 2006 [79] both Valtropin and Omnitrope have chosen the most sensitive model (prepubertal children with GH deficiency) with stable thyroid hormone and/or glucocorticoid replacement therapies if indicated, to show comparative efficacy and safety to the reference biological medicinal product.

Omnitrope contains human $\mathrm{GH}$ produced by recombinant technology using $E$. coli as expression system. During the clinical development program various formulations of GH were used, with the active pharmaceutical ingredient, as follows.

Somatropin Sandoz powder for solution for injection (Covance).

Somatropin Sandoz powder (Sandoz): formulation to be marketed as Omnitrope.

Somatropin Sandoz liquid (Sandoz).

The effect of Omnitrope (Covance) was compared in 89 naive children with GHD to Genotropin (Pfizer). Efficacy was similar, the Covance formulation however led to a high titer of $\mathrm{GH}$ antibodies (ABs) (60\%) without adverse effects on growth velocity [11].

These ABs did not affect efficacy or safety of the biosimilar. Their occurrence was most likely related to the presence of an increased level of host cell protein. After introduction of additional purification steps $A B$ frequency dropped to the accepted range [16]. In subsequent Omnitrope formulations no patient developed antibodies against GH and 1 patient 
TABLE 3: Results from omnitrope and valtropin trials [2, 11, 12]. SDS: standard deviation score; PP = per protocol; NS: not significant; CI: confidence interval.

\begin{tabular}{|c|c|c|c|}
\hline & Omnitrope & Genotropin & $95 \% \mathrm{CI}$ \\
\hline Number of Patients & 44 & 45 & \\
\hline Duration, months & 9 & 9 & \\
\hline Height baseline, $\mathrm{cm}$ & 113.3 & 109.3 & \\
\hline Height at 9 months, $\mathrm{cm}$ & 121.9 & 117.7 & $-0.59,1.06$ \\
\hline Height velocity pretreatment, $\mathrm{cm} /$ year & 3.8 & 4.0 & \\
\hline Height velocity at 9 months, $\mathrm{cm} /$ year & 10.7 & 10.7 & $-1.35,0.92$ \\
\hline Height velocity SDS at baseline, $\mathrm{cm} /$ year & -2.4 & -2.3 & \\
\hline \multirow[t]{2}{*}{ Height velocity SDS at 9 months, $\mathrm{cm} /$ year } & 6.1 & 5.4 & $-0.81,2.13$ \\
\hline & Valtropin & Humatrope & $95 \% \mathrm{CI}$ \\
\hline Number of Patients (PP) & $98(70)$ & $49(32)$ & \\
\hline Duration, months & 12 & 12 & \\
\hline Height baseline, $\mathrm{cm}$ & 108.4 & 111.3 & \\
\hline Height at 12 months, $\mathrm{cm}$ & 120.2 & 122.5 & NS \\
\hline Height velocity pretreatment, $\mathrm{cm} /$ year & 3.6 & 3.4 & \\
\hline Height velocity at 12 months, $\mathrm{cm} /$ year & 11.3 & 10.5 & $-0.71,0.90$ \\
\hline Height velocity SDS at baseline, $\mathrm{cm} /$ year & -2.19 & -2.42 & \\
\hline Height velocity SDS at 12 months, $\mathrm{cm} /$ year & 5.62 & 5.33 & NS \\
\hline
\end{tabular}

TABle 4: Auxological measurements at baseline and after 1 year of treatment with either Valtropin or Humatrope in children with GH deficiency $[11,12]$. Values are mean \pm SD with medians in parantheses. HV: height velocity; SDS: standard deviation score; CA: chronological age; $\mathrm{BA}=$ bone age.

\begin{tabular}{|c|c|c|}
\hline & Valtropin $N=70$ & Humatrope $N=32$ \\
\hline \multicolumn{3}{|l|}{ HV SDS CA } \\
\hline Pretreatment & $-2.19 \pm 1.80(-1.79)$ & $-2.42 \pm 1.37(-2.11)$ \\
\hline 12 months & $5.62 \pm 3.55(4.86)$ & $5.33 \pm 3.88(3.89)$ \\
\hline \multicolumn{3}{|l|}{ Height SDS CA } \\
\hline Baseline & $-3.45 \pm 1.16(-3.24)$ & $-3.17 \pm 0.80(-2.93)$ \\
\hline 12 months & $-2.26 \pm 0.91(-2.15)$ & $-2.15 \pm 0.69(-2.00)$ \\
\hline \multicolumn{3}{|l|}{ Height SDS BA } \\
\hline Baseline & $-0.15 \pm 1.47(-0.20)$ & $-0.06 \pm 1.33(-0.08)$ \\
\hline 12 months & $-0.09 \pm 1.61(-0.27)$ & $-0.00 \pm 1.40(0.14)$ \\
\hline \multicolumn{3}{|l|}{ IGF-I, $\mu \mathrm{g} / \mathrm{L}$} \\
\hline Baseline & $47.3 \pm 37.5(37.0)$ & $64.1 \pm 44.6(58.0)$ \\
\hline 12 months & $158.7 \pm 104.6(133.5)$ & $186.6 \pm 102.5(170.5)$ \\
\hline \multicolumn{3}{|l|}{ IGFBP-3, mg/L } \\
\hline Baseline & $1.3 \pm 0.8(1.2)$ & $1.6 \pm 0.9(1.3)$ \\
\hline 12 months & $2.4 \pm 0.7(2.5)$ & $2.7 \pm 0.7(2.8)$ \\
\hline
\end{tabular}

developed anti-HCP antibodies during the 12 months study (data on file with Sandoz).

These studies are still ongoing in the same cohort and a phase III study is now in its 7th year with centrally measured IGF-1, carbohydrate metabolism parameters, and antibodies against GH and host cell protein (HCP) [11].

Valtropin has been produced in S. cerevisiae (yeast cells). Valtropin was compared to Humatrope in terms of quality, safety, and efficacy. The registration trial was powered with $98 \mathrm{GH}$ deficient children in the Valtropin arm compared to 49 children in the Humatrope arm. This was a 12-months parallel controlled study. After the initial 12-months period, all enrolled patients were treated for an additional 12 month period. Height velocity increases were comparable with both products (see Table 3) [12].

These studies were powered according to strict FDA guidelines to detect noninferiority at a $1.8 \mathrm{~cm}$ growth velocity difference.

In addition, one uncontrolled 12 supportive study in 30 treatment-naïve girls aged 2-9 years with short stature due to Turner Syndrome was performed [17]. Height velocity increased significantly in this observational study from baseline values of $3.75+1.76 \mathrm{~cm} /$ year rose to $9.73+$ $1.55 \mathrm{~cm} /$ year. 
The Valtropin safety profile was consistent with that of Humatrope. There were no relevant differences in the development of anti-GH AB between Valtropin (2-3\%) and the reference product $(3 \%)$. Growth was not affected by $\mathrm{AB}$ status. The observed frequency of anti S. cerevisiae $\mathrm{AB}$ (2\%) did not raise concern as these $A B$ do not appear to have adjuvant properties, which could amplify the immune response (4.16).

PD data (rise in IGF-1 and IGFBP-3) are for both Omnitrope and Valtropin similarly reassuring when compared to Genotropin and Humatrope Table $4[4,11,12]$ (for Valtropin data see Table 4 and $[11,18]$ for Omnitrope).

\section{Areas of Concern}

It is unclear at present whether regulatory agencies will eventually allow commercial use of approved biosimilar somatropins in non-GH deficient states. In the current giudelines $[6-8,19]$ it is considered that the demonstration of similar efficacy and safety in GH deficient children can be extrapolated to other indications of the reference somatropins (Genotropin and Humatrope).

Current guidelines both in Europe and in the US [68,19 ] propose study durations of 6-12 months for a comparative efficacy and safety assessment in children. None of the currently approved biosimilar growth hormones "settled" for this guideline. All carried out studies for significantly longer periods of time (in the case of Omnitrope for 7 years thus far and in the case of Valtropin for more than 3 years $[18,20]$ ).

A common misconception about biosimilars is that there is the potential for reduced quality standards. This is definitely not the case, as all aspects of the comparability exercise have to be fulfilled in fully characterizing the product and demonstrating similarity or noninferiority [2].

Both products will be monitored in phase IV pharmacovigilance programs just like most of the other previously NDA approved somatropins. These risk-management programs take into account that long-term information is necessary for biosimilars as far as carbohydrate metabolism, $\mathrm{AB}$ formation, and the development of IGF-1 receptor expressing cancers. This approach has been in place for previously approved growth hormones and it is therefore reasonable to put a similar program in place for the class of FOPP or biosimilars medicinal GH products. Given the low frequency of adverse effects in all GH products only a long-term large pharmacopidemiological study will have a chance to detect adverse effects. The existing databases are insufficient to answer the question of tumor-growth promoting potential of GH effects [21]. Therefore these potential serious adverse side effects have to be explored for all growth hormones including biosimilars (B. Weise, personal comment).

The high $\mathrm{AB}$ titers in the initial Omnitrope product formulation manufactured by Covance are no longer found in patients receiving the currently marketed formulation. In fact anti-GH $\mathrm{AB}$ and anti-HCP $\mathrm{AB}$ titers are not different from the comparator Genotropin. GH is administered in an unphysiologic fashion, that is, by subcutaneous injection, there will therefore always be low level $\mathrm{AB}$ formation. Neutralizing or blocking $A B$ titers were never seen with any biosimilar or FOPP product.

Regarding the issue of switching patients receiving a growth hormone preparation to a biosimilar medicinal product, it is of interest that in a recent position paper by the Arzneimittelkommission (Drug Review Board) of the German Medical Association [22] voices no concern. The Board does not see any reason not to switch patients receiving a biopharmaceutical to a biosimilar medicinal product if so desired or requested because of lower cost. In other countries, including the US, third party payers increasingly demand similar changes as a cost-saving measure.

It has been argued [23] that the safety of biosimilars is not "on a par" with the knowledge gained through the previous approval processes for GH. This is not correct [24]. The previous growth hormones study data that were submitted after 12 months data from phase III studies were available and both EMEA and FDA require 6-12 months data for submission of biosimilars or FOPPs. Both LGLS/Biopartners and Sandoz submitted 12 months data. In the cases of Sandoz and LGLS/Biopartners now seven- and, respectively, threeyear safety data from phase III studies have been presented in abstract from $[18,20]$, providing a degree of scientific scrutiny absent from phase IV postmarketing studies. Ideally the final choice of product to be prescribed must be made by the informed physician [23]. Unfortunately this process is being dismantled in the US where payors increasingly prescribe which GH preparations can be used.

\section{Acknowledgments}

The author wishes to thank both Dr. M.Zabranski, Sandoz, and Dr. C. Savoy and J. van Wyngaard, Biopartners, for helpful discussions.

\section{References}

[1] D. M. Dudzinski and A. S. Kesselheim, "Scientific and legal viability of follow-on protein drugs," The New England Journal of Medicine, vol. 358, no. 8, pp. 843-849, 2008.

[2] "Editorial: regulating a moving frontier," Regulatory Rapporteur, vol. 6, pp. 8-9, 2009.

[3] European Generic Medicines Association (EGA), "Competition and Affordability in Biopharmaceuticals,” January 2009, http://www.egagenerics.com/ega-biosimilars.htm.

[4] M. Pavlovic, E. Girardin, L. Kapetanovic, K. Ho, and J.-H. Trouvin, "Similar biological medicinal products containing recombinant human growth hormone: European regulation," Hormone Research, vol. 69, no. 1, pp. 14-21, 2007.

[5] Complaint at 112-122, Sandoz, Inc.v. Leavitt (DDC 2006), 05cv-1810 c.

[6] Omnitrope, European Public Assessment Report, April 2006, http://www.emea.europa.eu/humandocs/Humans/EPAR/omnitrope/omnitrope.htm.

[7] Valtropin, European Public Assessment Report, April 2006, http://www.emea.europa.eu/humandocs/Humans/EPAR/valtropin/valtropin.htm. 
[8] Omnitrope (somatropin) questions and answers, US Food and Drug Administration, Center for Drug Evaluation and Research, http://www.fda.gov/cder/whatsnew.htm.

[9] Annex Guideline on Similar Biological Medicinal Products Containing Biotechnology-Derived Proteins as Active Substance: Non-Clinical and Clinical Issues-Guidance on Similar Medicinal Products Containing Somatropin, EMES/CHMP/94528/05, CHMP adopted, February 2006.

[10] "Testimony of Senator Charles E. Schumer HELP Committee Hearing on Follow-On Biologics March 8, 2007," Education, Labor and Pensions, February 2009, http://help.senate.gov/Hearings/2007_03_08/Schumer.pdf.

[11] T. Romer, F. Peter, P. Saenger, et al., "Efficacy and safety of a new ready-to-use recombinant human growth hormone solution," Journal of Endocrinological Investigation, vol. 30, no. 7, pp. 578-589, 2007.

[12] V. Peterkova, I. Arslanoglu, E. Bolshova-Zubkovskaya, et al., "A randomized, double-blind study to assess the efficacy and safety of valtropin, a biosimilar growth hormone, in children with growth hormone deficiency," Hormone Research, vol. 68, no. 6, pp. 288-293, 2007.

[13] H. Schellekens, "How similar do 'biosimilars' need to be?" Nature Biotechnology, vol. 22, no. 11, pp. 1357-1359, 2004.

[14] M. Kessler, D. Goldsmith, and H. Schellekens, "Immunogenicity of biopharmaceuticals," Nephrology Dialysis Transplantation, vol. 21, supplement 5, pp. v9-v12, 2006.

[15] S. Louët, "Lessons from Eprex for biogeneric firms," Nature Biotechnology, vol. 21, no. 9, pp. 956-957, 2003.

[16] C. K. Schneider and U. Kalinke, "Toward biosimilar monoclonal antibodies," Nature Biotechnology, vol. 26, no. 9, pp. 985-990, 2008.

[17] V. Peterkova, C. Savoy, O. Bezlepkina, et al., "Efficacy and safety of Valtropin ${ }^{\mathrm{TM}}$ in the treatment of short stature in girls with Turner's syndrome," Journal of Pediatric Endocrinology and Metabolism, vol. 17, no. 10, pp. 1429-1434, 2004.

[18] T. Romer, F. Peter, B. Koehler, et al., "Long-term treatment with Omnitrope $3.3 \mathrm{mg} / \mathrm{ml} \mathrm{ready-to-use} \mathrm{solution} \mathrm{of} \mathrm{short}$ children with growth hormone deficiency: 7 years follow up," Hormone Research, vol. 70, supplement 1, p. 105, 2008.

[19] Sandoz v. Leavitt (DDC 2006), 427 F. Supp. 2d 29,33 (DDC 2006).

[20] M. Walczak, D. Zdavkovic, E. Bolshova-Zubkovskaya, et al., "A 3 year assessment of the efficacy and safety profile of Valtropin, a recombinant human growth hormone, in children with growth hormone deficiency," Hormone Research, vol. 70, supplement 1, p. 97, 2008.

[21] M. A. Sperling, P. H. Saenger, R. Hintz, T. Wilson, and S. R. Rose, "Growth hormone treatment and neoplasia-coincidence or consequence?" The Journal of Clinical Endocrinology \& Metabolism, vol. 87, no. 12, pp. 5351-5352, 2002.

[22] Newsletter 2008-130, German Medical Association.Newsletter@akdae.de, January 2009.

[23] M. B. Ranke, "New preparations comprising recombinant human growth hormone: deliberations on the issue of biosimilars," Hormone Research, vol. 69, no. 1, pp. 22-28, 2007.

[24] W. Hoppe and A. Berghout, "Biosimilar somatropin: myths and facts," Hormone Research, vol. 69, no. 1, pp. 29-30, 2007. 